\title{
Factors associated with development of opportunistic infections among patients on ART at a Ugandan Program-MJAP
}

\author{
Simon Muhumuza*, Joseph Ouma, Fred Semitala \\ From $16^{\text {th }}$ International Symposium on HIV and Emerging Infectious Diseases \\ Marseille, France. 24-26 March 2010
}

\section{Background}

To establish the factors associated with development of opportunistic infections among patients on ART at an HIV/AIDS Program in Uganda.

\section{Methods}

Retrospective cohort analysis on adult patients initiated on ART between November 2005 and November 2007. The socio demographics, clinical and laboratory characteristics of patients that developed OIs were studied.

\section{Results}

Data of 4,878 patients on ART was analyzed. 3,247 (67.2\%) were females. Median age 33 years (SD 8.5) and Median weight $53 \mathrm{~kg}$ (SD 10.0). Incidence of OIs 329 (6.7\%); Oral candidiasis 106 (32\%), Vaginal candidiasis 80 (24\%), Kaposi's sarcoma 40 (12\%), Herpes simplex 28 (9\%), Oesophageal candidiasis 25 (8\%), Tuberculosis 15 (5\%), others $38(10 \%)$. WHO stage $3 \& 4$ (OR 2.64, CI 2.04-3.43, $\mathrm{P}<0.001$ ), CD4 count $<100$ cells $/ \mathrm{mm}^{3}$ (OR 1.92, CI 1.52-2.42, $\mathrm{P}<0.001$ ), not being married (OR 1.69, CI 1.33-2.14, $\mathrm{P}<0.001$ ) and having no formal education (OR 1.61 CI 1.09-2.36, P = .0015) were significantly associated with development of OIs among patients on ART.

Sex, age, body weight, ART regimen and Karnofsky score were not associated with development of OIs.

\section{Discussion}

The risk of OIs is higher among patients with a low CD4 count, high WHO clinical stage, no formal education and in those that are not married.

\footnotetext{
* Correspondence: simonmhmz@yahoo.com
}

Mulago-Mbarara Teaching Hospitals Joint AIDS Program (MJAP), Kampala, Uganda
Early identification of HIV-infected individuals and linkage to HIV care and treatment is likely to minimize the incidence of Opportunistic Infections.

Published: 11 May 2010

doi:10.1186/1742-4690-7-S1-P77

Cite this article as: Muhumuza et al:: Factors associated with development of opportunistic infections among patients on ART at a Ugandan Program-MJAP. Retrovirology 2010 7(Suppl 1):P77.
Submit your next manuscript to BioMed Central and take full advantage of:

- Convenient online submission

- Thorough peer review

- No space constraints or color figure charges

- Immediate publication on acceptance

- Inclusion in PubMed, CAS, Scopus and Google Scholar

- Research which is freely available for redistribution

Submit your manuscript at www.biomedcentral.com/submit
C Biomed Central 